\title{
The Role of PGC-1 $\alpha$ in the Development of Insulin Resistance in Skeletal Muscle - Revisited
}

\author{
Bartlomiej Łukaszuk Krzysztof Kurek Agnieszka Mikłosz \\ Małgorzata Żendzian-Piotrowska Adrian Chabowski \\ Department of Physiology, Medical University of Bialystok, Bialystok, Poland
}

\section{Key Words}

PGC-1 $\cdot$ - Skeletal muscle insulin resistance $\cdot$ Bioactive lipids $•$ Ceramide $\cdot$ Diacylglycerol

\begin{abstract}
Currently, obesity is a predominant medical condition and an important risk factor for the development of several diseases, including type 2 diabetes mellitus. Importantly, most research has indicated lipid-induced insulin resistance in skeletal muscles is a key link between the aforementioned pathological conditions. PGC-1 $\alpha$ is a prominent regulator of myocellular energy metabolism orchestrating gene transcription programming in response to numerous environmental stimuli. Moreover, it is widely acknowledged that mitochondrial metabolism (primary metabolic target of PGC-1 $\alpha$ ) disturbances are widely acknowledged contributors to type 2 diabetes development. Therefore, it seems surprising that the exact physiological contribution of PGC-1 $\alpha$ in the development of insulin resistance in skeletal muscle remains poorly understood. This review aims to reconcile these allegedly different findings by looking for a common denominator in the role(s) of PGC-1 $\alpha$ in respect to lipid-induced insulin resistance in skeletal muscle. Our scrutiny of the literature indicates that interventions at the level of PGC$1 \alpha$ may exert beneficial effects on myocytes in respect to lipid-induced insulin resistance. The latter takes place as a result of a positive net energy balance (fatty acids oxidation surpassing their accumulation rate). Moreover, the aforementioned effects may not necessarily be limited to physically active states. They seem to occur, however, only within a physiologically observed range in muscle cells (approximately 1 -fold changes in PGC-1 $\alpha$ protein expression).
\end{abstract}

\section{Introduction}

Obesity is currently a predominant medical condition because for several dozens of years an alarming increase in its prevalence has been observed. Currently, according to the World Health Organization (WHO), approximately 1.9 billion adults are overweight, and over $30 \%$ of 
these individuals are obese [1]. Unfortunately, raised body mass index (BMI) is an important risk factor for the development of several diseases, including insulin resistance (IR) and type 2 diabetes mellitus (T2DM) [1, 2]. Moreover, a particular emphasis has been placed on lipidmediated impairments of the insulin sensitivity in skeletal muscles because the vast majority (approximately 80\%) of ingested glucose is utilized by myocytes, thus greatly affecting the whole body glucose clearance [3]. Although the exact causes of IR are still a matter of intense debate, the available literature data indicate an imbalance between an excessive cellular free fatty acids (FFAs) influx and an insufficient myocyte oxidative capacity as the most probable source of its origin [4-6]. The resultant lipid overload, especially for diacylglycerol (DAG) and ceramide (CER), directly interferes with myocellular insulin signal transduction $[7,8]$. It seems that affecting either the influx of FAs into the cell or their oxidation is still promising, despite debatable, therapeutic approaches. Both these aforementioned processes are tightly regulated by a set of nuclear receptors called peroxisome proliferator-activated receptors (PPARs) $[9,10]$. PPAR $\gamma$ coactivator $1-\alpha$ (PGC-1 $\alpha$ ) is one of the best characterized regulatory proteins, and it interacts with numerous nuclear receptors (including PPARs) and regulates various aspects of cellular energy metabolism, mainly via the regulation of mitochondria number and functions [11-14]. Interestingly, recent data imply that PGC-1 $\alpha$ is also involved in the uptake, storage and turnover of glucose and FFAs $[15,16]$. This review focuses on the recent advances in research on the role of PGC-1 $\alpha$ in the development of skeletal muscle insulin resistance.

\section{The lipid-centric view of insulin resistance}

The relationship between body fat deposits and the resulting insulin resistance is now well established, because it has been extensively studied in human and animal models [2, 17]. With a prolonged positive caloric energy balance, which frequently occurs in obesity, the adipocyte storage capacity is exceeded, which results in an increase in plasma long chain fatty acids (LCFAs) content and subsequent ectopic lipid accumulation [17]. This phenomenon, namely the accumulation of bioactive lipids in the not adapted for this purpose peripheral tissues (e.g. liver, heart and skeletal muscles), was termed lipotoxicity and it is acknowledged as a major factor that causes dysfunctions in insulin signaling [17-19]. Moreover, it was demonstrated that even a short, overnight intravenous lipid infusion leads to a significant elevation in the intracellular lipid content (IMCL) and subsequent reductions in muscular insulin sensitivity [20]. Nonetheless, the exact cellular mechanism of the action of lipids still needs to be determined. One should also be aware of a particular metabolic paradox, namely that the aforementioned negative correlation between the IMCL amount and muscular insulin sensitivity was observed only for average sedentary subjects. In the case of trained athletes, however, this does not seem to be true, because in these individuals, the increased lipid content is accompanied by well-preserved insulin responsiveness [21]. For these reasons, most authors highlight the intermediate lipid metabolites, mainly DAG and CER, but not simple myocyte lipid overload as a probable direct cause of insulin resistance $[7,8,22]$.

\section{Bioactive lipid intermediates and insulin signaling pathway}

The amount of scientific literature concerning the diacylglycerol- and ceramide-induced disruption of the insulin signaling pathway [7, 8, 18, 23], with their key routes depicted in Fig. 1, is growing. The increased level of both lipid fractions has been reported in the muscular tissue of obese humans and rodents [24, 25]. Furthermore, interventions aiming to reduce the synthesis of CER $[23,26]$ and/or DAG [8] have proven successful in restoring insulin sensitivity in skeletal muscles. Moreover, some beneficial effects of exercise training 


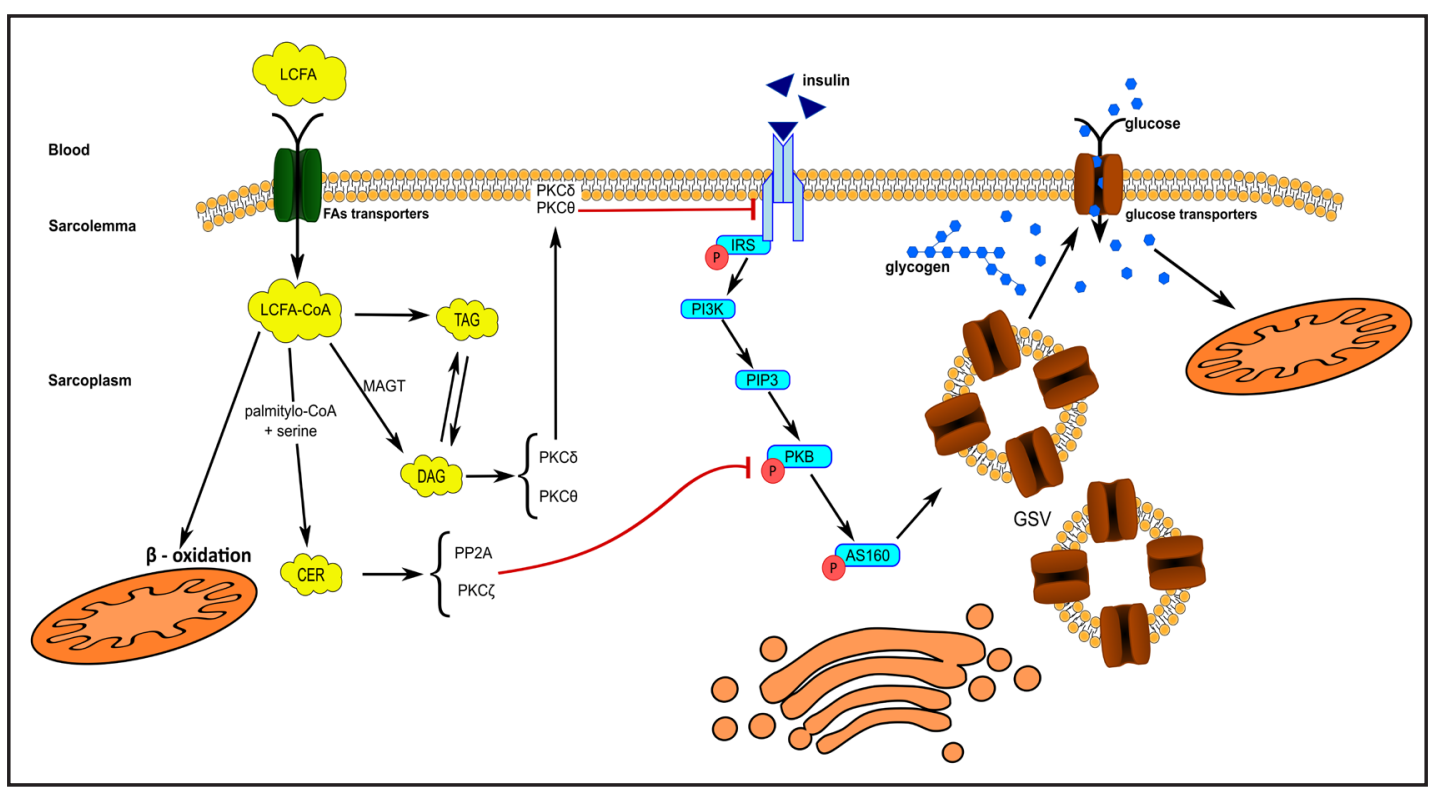

Fig. 1. Bioactive lipid species and insulin signaling pathway. Adopted from [29].

have been attributed to reductions in muscular DAG and CER content [25].

Intramuscular DAG accumulation is believed to disrupt the insulin signaling cascade via the activation of conventional and novel protein kinases ( $\mathrm{PKC} \beta, \mathrm{PKC} \delta$, and $\mathrm{PKC} \theta$ ), which in turn deactivates the insulin receptor substrate (IRS-1) protein by the phosphorylation of its serine residue $[8,24]$. However, the relationship between the DAG concentration and IR seems to be more complex because not all studies have found direct interactions [27]. Perhaps this is due to different levels of DAG fatty acids saturation status, with mono- and polyunsaturated FAs species favoring insulin sensitivity [28]. On the other hand, the actions of ceramide in respect to insulin signaling pathway, seem to be more diversified [7]. The over-accumulation of ceramide activates cytosolic protein phosphatase 2A (PP2A) which promotes the dephosphorylation of serine $\left(\mathrm{Ser}^{473}\right)$ and threonine $\left(\mathrm{Thr}^{308}\right)$ in PKB disabling its translocation to the plasma membrane [7]. Secondly, it interferes with the phosphorylation of PKB (via PKC $\zeta$ ) thus leaving PKB in an inactive state and preventing further insulin signal transduction $[7,29]$. In addition, ceramide may also activate c-Jun N-terminal kinase (JNK), a well-known protein kinase involved in inflammatory responses [7, 25]. However, Lee and co-workers [30] have demonstrated in an immuno-compromised rodent model (Jun NH(2)terminal kinase-deficient mice), that a short term (3 days) high fat diet (HFD) feeding was able to induce IR, independent of inflammation. Therefore, it seems that the last of the discussed mechanisms is more important once obesity is established and not in the early stages of lipid-induced insulin resistance [25, 30]. Interestingly, some reports have indicated that CER may also exert an influence on the fluidity of the plasma membrane, thus impairing the translocation and fusion processes of glucose storage vesicles (GSV) [7].

\section{PGC-1 $\alpha$ and insulin resistance in skeletal muscle}

PGC- $1 \alpha$ is a prominent regulator of cellular energy metabolism orchestrating gene transcription programming in response to numerous environmental stimuli. In skeletal muscles it is specifically involved in a wide range of different processes including: fiber type phenotype, muscle mass maintenance, angiogenesis and neuromuscular junction remodeling $[11,31]$. However, the main and best studied role of PGC- $1 \alpha$ in myocytes is the regulation of mitochondrial substrate utilization [11-13]. Amongst the most important targets of PGC-1 $\alpha$ in skeletal muscles are: nuclear respiratory factors (NRFs), estrogen related receptors (ERRs) 
and PPARs [11]. Both NRFs and ERRs are indispensable for mitochondrial proliferation and cell respiration; whereas PPARs are vitally involved in the regulation of carbohydrate, protein and lipid metabolism [11]. Interestingly, the antidiabetic drugs, metformin and thiazolidinediones, exert some of their therapeutic properties via PPAR activation [32].

There are several distinct genetic variants of PGC- $1 \alpha$, and some of them are correlated with the onset of insulin resistance and type 2 diabetes [12, 33, 34]. Additionally, either PGC- $1 \alpha$ itself or its target genes are frequently downregulated in human $[35,36]$ and/or animal models of diabetes [37]. Moreover, mitochondrial metabolism (primary metabolic target of PGC-1 $\alpha$ ) disturbances are widely acknowledged contributors to the development of type 2 diabetes [11]. Therefore, it seems even more surprising that the exact physiological role of PGC-1 $\alpha$ in the development of insulin resistance in skeletal muscle remains poorly understood. A study conducted by Lin and co-workers has shown that PGC- $1 \alpha$ null mice are insulin sensitive not only on a standard rodent chow diet, but also when challenged with a high caloric regime [38]. The reason for this may lay in the complex tissue-divergent role of PGC- $1 \alpha$. The aforementioned mice, for example, were also lean and hyperactive which suggests that central nervous system (CNS)-specific actions may override the influence of PGC- $1 \alpha$ on metabolism in the peripheral tissues [38]. For these reasons, we decided to limit the scope of our review to research examining the role of PGC- $1 \alpha$ in the peripheral tissues, namely skeletal muscles (Table 1).

Careful review of the literature data (Table 1) indicates that PGC- $1 \alpha$ found in skeletal muscle may perform a few quite different cellular actions in respect to fat metabolism. First, the coactivator seems to regulate both ends of the energetic metabolic spectrum, i.e. anabolic (uptake and storage) and catabolic (utilization). In general, PGC- $1 \alpha$ increases lipogenesis and lipid accumulation by upregulating a set of cellular processes. It upregulates: 1) fatty acids transport - by changing the expression patterns of: fatty acid translocase (FAT/CD36) [15, 16, 39-41], fatty acid transport proteins (FATP-1, 4) [39, 41], plasma membrane Fatty Acid Binding Protein (FABPpm) [16], and lipoprotein lipase (LPL) [15]. It also upregulates FA biosynthesis - by influencing the activities of: fatty acid synthase (FAS) $[39,42]$ and acetyl-CoA carboxylase (ACC) $[15,42]$. On the other hand, it also stimulates fatty acid usage by increasing the number of mitochondria $[16,40,43]$ and/or their intrinsic oxidative capacity $[15,29,41-43]$. Interestingly, some studies have suggested that PGC-1 $\alpha$ overexpression may predispose individuals towards greater lipids utilization at the expense of carbohydrates, either during rest [43] or exercise [41]. Perhaps this dualistic nature of PGC- $1 \alpha$ (simultaneous fatty acids uptake/storage and oxidation) reflects its important physiological role in metabolic adaptations to physical exercise because in the muscles of athletes, both the concentration of lipids and oxidative capacity are concomitantly increased [44]. However, because of inconsistent data, it is far more difficult to define the net effect of PGC-1 $\alpha$ stimulation, whether there is an energy storage [15] or utilization prevalence [42] (Table 1). Some of the presented data indicate that PGC-1 $\alpha$ exerts its positive influence, by lowering myocellular lipid accumulation, only during regular stimulation by physical activity $[15,40]$. For example, Choi et al. [40] demonstrated that in sedentary animals the musclespecific overexpression of PGC-1 $\alpha$ was accompanied by decreases in glucose uptake and glycogen synthesis together with an increase in lipids accumulation (increased TAG content). Moreover, the authors reported an increase in membrane/cytosol DAG ratio followed by enhanced PKC $\theta$ activity and its translocation from the cytosol to the plasma membrane (Fig. 1) [40]. On the contrary, Summermatter et al. [15] indicateds that although PGC-1 $\alpha$ transgenic mice did suffer from the accelerated development of IR, they also gained greater benefits from physical activity. If it were true, and PGC- $1 \alpha$ positive effects were limited to only physically active states, then its pharmacological targeting would be of little practical value to obese individuals who are usually characterized by sedentary behavior and a reluctance towards physical activity. The aforementioned data, however, seem to be contradicted by the studies of Espinoza et al. [42] and Benton et al. [16]. In the latter study, it was indicated that PGC-1 $\alpha$ may improve lipid metabolism (decrease the intracellular amount of TAG, DAG and CER) in the muscles of sedentary obese Zucker rats [16]. It is hard to explain these

\section{KARGER}


Łukaszuk et al.: PGC-1 $\alpha$ and Muscular Insulin Resistance

Table 1. PGC-1 $\alpha$ muscle specific interventions with respect to glucose and lipid metabolism

\begin{tabular}{|c|c|c|c|c|}
\hline & First author & Experimental model & $\begin{array}{l}\text { Change with } \\
\text { respect to PGC- } 1 \alpha\end{array}$ & Important findings \\
\hline \multirow[t]{2}{*}{1.} & $\begin{array}{l}\text { Summermatter S. } \\
\text { [39] }\end{array}$ & $\begin{array}{l}\text { transgenic (TG) vs. wild type (WT') } \\
\text { mice }\end{array}$ & $\begin{array}{l}\text { skeletal muscle } \\
\text { specific } \\
\text { overexpression }\end{array}$ & $\begin{array}{l}\uparrow \text { lipogenesis }(\approx+44 \%) \text { and lipid accumulation } \\
\uparrow \text { FAS protein expression }(\approx+50 \%) \text { and activity }(\approx+131 \%) \\
\uparrow \text { FAT/CD36 mRNA }(\approx+2 \text { fold), } \uparrow \text { FATP-4 mRNA }(\approx+1 \text { fold }) \\
\uparrow \text { DGAT- } 1 \text { mRNA }(\approx+51 \%)-\text { formation of TAG from DAG, } \\
\uparrow \text { mtGPAT }(\approx+150 \%) \\
\uparrow \text { GLUT }-4 \text { mRNA }(\approx+50 \%) \\
\text { १lucose uptake }(\approx+48 \%)\end{array}$ \\
\hline & & $\mathrm{C} 2 \mathrm{C} 12$ cell line & overexpression & $\begin{array}{l}\uparrow F A S \text { mRNA }(z+40 \%) \\
\uparrow F A S \text { activity }(\approx+50 \%) \\
\uparrow \text { lipogenesis }(\approx+30 \%)\end{array}$ \\
\hline 2. & $\begin{array}{l}\text { Espinoza D. } 0 . \\
{[42]}\end{array}$ & $\mathrm{C} 2 \mathrm{C} 12$ cell line & overexpression & $\begin{array}{l}\uparrow \text { palmitate oxidation }(\approx+31 \%) \\
\downarrow \text { palmitate uptake }(\approx-6 \%) \text {; } \\
\uparrow \text { mRNA - genes for lipid oxidation (CPT1b, ACADL/M) and synthesis } \\
\text { (FAS, CS, ACC1/2 and DGAT1); } \\
\downarrow \text { total lipid content }(\approx-42 \%) \text { (palmitate-loaded serum-starved cells); } \\
\uparrow \text { FA synthesis from glucose and by elongation }\end{array}$ \\
\hline 3. & $\begin{array}{l}\text { Summermatter } S \text {. } \\
{[15]}\end{array}$ & $\begin{array}{l}\text { mice divided into } 4 \text { groups: } \\
\text { HFD-wild type-sedentary } \\
\text { HFD-wild type-exercised } \\
\text { HFD-PGC- } 1 \alpha(+) \text {-sedentary } \\
\text { HFD-PGC- } 1 \alpha(+) \text { - exercised }\end{array}$ & $\begin{array}{l}\text { skeletal muscle } \\
\text { specific } \\
\text { overexpression }\end{array}$ & $\begin{array}{l}\text { PGC- } 1 \alpha(+) \text { animals } \\
\uparrow \text { body mass and fat mass } \\
\uparrow \text { accelerated development of IR by } 2 \text { week HFD feeding } \\
\downarrow \text { GLUT- } 4 \text { mRNA and glucose uptake } \\
\uparrow \text { LPL and FAT/CD } 36 \text { mRNA } \\
\uparrow \text { mRNA for CPT-1, MCD, ACC2, CS } \\
\text { lipids uptake > lipids oxidation } \\
\uparrow \text { DAG, but not TAG nor CER } \\
\uparrow \text { benefits from training }\end{array}$ \\
\hline 4. & $\begin{array}{l}\text { Choi C. S. } \\
{[40]}\end{array}$ & $\begin{array}{l}\text { mice divided onto } 4 \text { groups: } \\
\text { Chow diet- wild type } \\
\text { HFD- wild type } \\
\text { Chow diet-PGC- } 1 \alpha(+) \\
\text { HFD- PGC-1 } \alpha(+)\end{array}$ & $\begin{array}{l}\text { skeletal muscle } \\
\text { specific } \\
\text { overexpression }\end{array}$ & 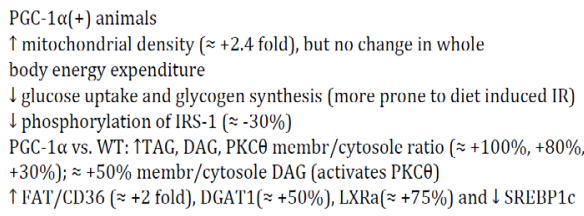 \\
\hline 5. & $\begin{array}{l}\text { Benton C. R. } \\
{[16]}\end{array}$ & $\begin{array}{l}\text { lean and obese Zucker rats } \\
\text { (with electrotransfected } \\
\text { upregulation of } \mathrm{PGC}-1 \alpha \\
\text { in muscle) }\end{array}$ & overexperssion & $\begin{array}{l}\uparrow \text { mitochondrial density } \\
\text { positive correlation between PGC- } 1 \alpha \text { level and GLUT4, FAT/CD36, } \\
\text { FABPpm, COX-IV } \\
\uparrow \text { insulin stimulated glucose transport in lean ( } \approx+19 \%) \text { and obese } \\
(\approx+21 \%) \text { muscles } \\
\uparrow \text { GLUT4 protein expression }(\approx+13 \%, 21 \% \text { for lean and obese } \\
\text { muscles respectively), } \\
\downarrow \text { TAG }(\approx-60 \%) \text { in obese, but } \uparrow \text { TAG }(\approx+31 \%) \text { in lean muscles } \\
\downarrow \text { DAG }(\approx-20 \%) \text { and CER }(\tilde{z}-28 \%) \text { in obese muslces } \\
\uparrow \text { FAT/CD36 protein level }(\approx+25 \% \text { and }+16 \% \text { in lean and obese muscles) } \\
\uparrow \text { subsarcolemmal, but not intramyofibrillar, mitochondrial oxidation } \\
(\approx+37 \% \text { and }+18 \%)\end{array}$ \\
\hline 6. & $\begin{array}{l}\text { Lukaszuk B. } \\
{[29]}\end{array}$ & L6 myotubes & $\begin{array}{l}\text { downregulation, } \\
\text { knock-down }\end{array}$ & $\begin{array}{l}\downarrow \text { Cyt C and } \beta \text {-HAD protein expression ( } \approx-16 \%,-19 \%) \\
\downarrow \text { pAMPK/AMPK }(\approx-20 \%) ; \uparrow \text { FASN } \\
\uparrow \text { TAG }(\approx+75 \%) \text { content, } \\
\text { no changes in FAs or glucose transporters expression; no changes in basal } \\
\text { palmitic acid or insulin stimulated glucose uptake }\end{array}$ \\
\hline 7. & $\begin{array}{l}\text { Hoeks J. } \\
{[43]}\end{array}$ & $\begin{array}{l}\text { transgenic mice vs. wild type } \\
\text { mice }\end{array}$ & overexpression & $\begin{array}{l}\uparrow \text { number of mitochondria ( } \approx+4.5 \text { fold) } \\
\uparrow \text { intrinsic mitochondrial capacity for fat, but not carbohydrate, oxidation } \\
\uparrow C S \text { and } \beta \text {-HAD activity per mitochondrion }(\approx+1.6 \text { fold and }+1.5 \text { fold, } \\
\text { respectively) } \\
\uparrow A T P \text { production for carbohydrates (due to } \uparrow \text { mitochondrial mass) } \\
\text { and fats ( } \uparrow \text { mitochondrial mass and intrinsic mitochondrial capacity) }\end{array}$ \\
\hline 8. & $\begin{array}{l}\text { Calvo J. A. } \\
\text { [41] }\end{array}$ & transgenic mice & $\begin{array}{l}\text { muscle specific } \\
\text { overexpression } \\
\text { of } \mathrm{PGC}-1 \text { alpha }\end{array}$ & $\begin{array}{l}\text { no differences in body weight nor body composition } \\
\uparrow \text { exercise capacity (greater speed and traveled distance) } \\
\uparrow \text { peak } \dot{V} 0_{2}(\approx+24 \% \text { ) } \\
\text { greater reliance on fatty acids during exercise but not during resting } \\
\text { (determined by RER values) } \\
\text { no change in insulin sensitivity (ITT-insulin tolerance test, and OGTT) } \\
\uparrow \text { mRNA level for: cytochrome c, CS, PDK4 (induces fatty acid oxidation at } \\
\text { the expense of glycolysis through the phosphorylation and inactivation of } \\
\text { the PDH enzyme complex), FAT/CD36, FATP- } 1 \text {, CPT- } 1 \text { b, MCAD (one of the } \\
\text { beta-oxidation enzymes), COXIV, ROS-scavenging genes, } \approx 57.6 \% \text { increase } \\
\text { in glycogen stores in skeletal muscle in the fed state }\end{array}$ \\
\hline
\end{tabular}

discrepancies, but perhaps they could be attributed to the different experimental models (in vivo [15, 40] versus in vitro [42]) and/or the degree of the overexpression of the coactivator (few fold $[15,40]$ versus $\sim 25 \%[16]$ ). The latter seems to be a particularly important 


\section{Cellular Physiology Cell Physiol Biochem 2015;37:2288-2296 \begin{tabular}{l|l|l} 
and Biochemistry Published online: December 02, 2015 & $\begin{array}{l}\text { (c) } 2015 \text { The Author(s). Published by S. Karger AG, Basel } \\
\text { www.karger.com/cpb }\end{array}$ \\
\hline
\end{tabular}}

suggestion because the dose response relationship is a well-documented phenomenon with respect to drugs [45], hormones [46] and regulatory proteins [47]. Moreover, other studies examining the relationship between the protein expression of PGC-1 $\alpha$ and the muscle fiber type indicate that relatively small changes (approximately $+/$ - 1-fold) in the coactivator content are sufficient to confer different muscular oxidative properties $[48,49]$. Therefore, it seems that even a relatively small shift in the PGC- $1 \alpha$ abundance may exert a significant physiological role. Keeping this in mind we recently conducted a study measuring the effects of modest PGC- $1 \alpha$ silencing (a - $24 \%$ decrease in protein content) in skeletal muscle cell lines [29], which appeared to confirm some of the findings of Benton et al. We revealed that the intracellular lipid content increased for TAG (+75\%), but not DAG nor CER. Importantly, this change seems to be caused by the decreased oxidative capacity for FAs, as confirmed by the reduced levels of cytochrome $C$ (Cyt $C$ ), beta-hydroxyacyl-CoA dehydrogenase ( $\beta$-HAD) and AMP activated protein kinase activity (pAMPK/AMPK ratio). Moreover, we found no evidence for the increased uptake of FAs, as there was no change in the expression of total fatty acid transport proteins nor basal palmitic acid uptake, and only limited support for an increase in lipogenesis, as there was an increase in FASN expression accompanied by a possible decrease in ACC activity [29]. Therefore, it seems that the modest down-regulation of PGC-1 $\alpha$ mimics the symptoms observed in the early stages of the development of insulin resistance. Moreover, in accordance with the suggestions of Benton et al. [16], modest interventions (< $100 \%$ ) of the PGC-1 $\alpha$ protein level may have therapeutic properties by changing the rate of mitochondrial FA oxidation without a subsequent increase in their uptake, storage and/or synthesis.

Additionally, most of the discussed research did not test the possible compensatory effects exerted by other members of PGC- 1 family $[\mathrm{PGC}-1 \beta$ and peroxisome related coactivator (PRC)]. This may be of particular importance, however, because some studies have indicated the possible synergistic actions of these coactivators. Lai et al. [50], for example, demonstrated that both PGC-1 $\alpha$ (PGC-1 $\alpha-/-)$ and PGC- $1 \beta$ (PGC- $1 \beta-/-)$ deficient mice presented only mild developmental disorders in their heart functions. Conversely, strikingly different situation occurred in the case of concomitant deficiency of the pair of coactivators. The aforementioned PGC-1 $\alpha \beta(-/-)$ phenotype was lethal with pronounced heart defects (bradycardia, intermittent heart block and significantly reduced cardiac output) [50]. This report indicated that both PGC-1 coactivators regulate at least partially overlapping metabolic programs potentially activating collateral 'rescue pathways'. However, much less is known about the possible convergent and/or compensatory effects of PGC- $1 \alpha$ and its third homolog, PRC.

Thus it seems that despite almost 20 years of research [51], and a significant improvement in our understanding of PGC- $1 \alpha$ biology, the exact role of this coactivator in lipid-induced insulin resistance in skeletal muscle still remains to be determined.

\section{Conclusions}

In summary, PGC- $1 \alpha$ is an important regulatory protein that is substantially and dually involved in the regulation of skeletal muscle energy metabolism. It simultaneously triggers the expression of genes involved in lipid transport/storage as well as their utilization, thus potentially reflecting its important physiological role in metabolic adaptations to physical exercise. It was postulated that the beneficial effects of PGC- $1 \alpha$ in myocytes (a positive net energy balance as a result of fatty acids oxidation surpassing their accumulation) are limited only to physically active states. Whether this is accurate needs further investigation. With this in mind there are few things to note. Most of the previous research focused on high (up to +21 -folds) levels of PGC-1 $\alpha$ overexpression $[16,48]$. Any research targeting PGC- $1 \alpha$ expression should evaluate the levels of its closest structural homologs (PGC-1 $\beta$ and PRC) to exclude the possibility of compensatory effect(s). Additionally, different PGC- $1 \alpha$ splice 
variants have been identified [52] with possibly different metabolic functions which should be taken into consideration, if possible, when designing new research.

\section{Acknowledgements}

This work was supported by the Medical University of Bialystok grant no. N/ST/ MN/15/003/1118 (154-18703L), 12/KNOW/2013 and the NCN grant no. 2012/07/N/ NZ3/01615.

\section{Disclosure Statement}

The authors declare no conflict of interests.

\section{References}

1 Media centre. Obesity and overweight. Fact sheet no311. http://www.who.int/mediacentre/factsheets/ fs311/en/. World Health Organization, 2015.

2 Smith U: Abdominal obesity: A marker of ectopic fat accumulation. J Clin Invest 2015;125:1790-1792.

3 DeFronzo RA, Tripathy D: Skeletal muscle insulin resistance is the primary defect in type 2 diabetes. Diabetes Care 2009;32:S157-163.

4 Snel M, Jonker JT, Schoones J, Lamb H, de Roos A, Pijl H, Smit JW, Meinders AE, Jazet IM: Ectopic fat and insulin resistance: Pathophysiology and effect of diet and lifestyle interventions. Int J Endocrinol 2012;2012:983814.

-5 Zhang L, Keung W, Samokhvalov V, Wang W, Lopaschuk GD: Role of fatty acid uptake and fatty acid betaoxidation in mediating insulin resistance in heart and skeletal muscle. Biochim Biophys Acta 2010;1801:122.

6 Holloway GP: Mitochondrial function and dysfunction in exercise and insulin resistance. Appl Physiol Nutr Metab 2009;34:440-446.

7 Larsen PJ, Tennagels N: On ceramides, other sphingolipids and impaired glucose homeostasis. Mol Metab 2014;3:252-260.

8 Timmers S, Schrauwen P, de Vogel J: Muscular diacylglycerol metabolism and insulin resistance. Physiol Behav 2008;94:242-251.

9 Sugden MC, Zariwala MG, Holness MJ: Ppars and the orchestration of metabolic fuel selection. Pharmacol Res 2009;60:141-150.

10 Tyagi S, Gupta P, Saini AS, Kaushal C, Sharma S: The peroxisome proliferator-activated receptor: A family of nuclear receptors role in various diseases. J Adv Pharm Technol Res 2011;2:236-240.

11 Arany Z: Pgc-1 coactivators and skeletal muscle adaptations in health and disease. Curr Opin Genet Dev 2008;18:426-434.

12 Rowe GC, Arany Z: Genetic models of pgc-1 and glucose metabolism and homeostasis. Rev Endocr Metab Disord 2014;15:21-29.

13 Buler M, Aatsinki SM, Izzi V, Uusimaa J, Hakkola J: Sirt5 is under the control of pgc-1alpha and ampk and is involved in regulation of mitochondrial energy metabolism. FASEB J 2014;28:3225-3237.

14 Sun L, Zang WJ, Wang H, Zhao M, Yu XJ, He X, Miao Y, Zhou J: Acetylcholine promotes ros detoxification against hypoxia/reoxygenation-induced oxidative stress through foxo3a/pgc-1alpha dependent superoxide dismutase. Cell Physiol Biochem 2014;34:1614-1625.

15 Summermatter S, Shui G, Maag D, Santos G, Wenk MR, Handschin C: Pgc-1alpha improves glucose homeostasis in skeletal muscle in an activity-dependent manner. Diabetes 2013;62:85-95.

-16 Benton CR, Holloway GP, Han XX, Yoshida Y, Snook LA, Lally J, Glatz JF, Luiken JJ, Chabowski A, Bonen A: Increased levels of peroxisome proliferator-activated receptor gamma, coactivator 1 alpha (pgc-1alpha) improve lipid utilisation, insulin signalling and glucose transport in skeletal muscle of lean and insulinresistant obese zucker rats. Diabetologia 2010;53:2008-2019. 


\section{Cellular Physiology Cell Physiol Biochem 2015;37:2288-2296 and Biochemistry Published $\begin{aligned} & \text { DOI: 10.1159/000438584 } \\ & \text { C } 2015 \text { The Author(s). Published by S. Karger AG, Basel } \\ & \text { www.karger.com/cpb }\end{aligned}$}

Łukaszuk et al.: PGC-1 $\alpha$ and Muscular Insulin Resistance

17 Capurso C, Capurso A: From excess adiposity to insulin resistance: The role of free fatty acids. Vascul Pharmacol 2012;57:91-97.

18 Bosma M, Kersten S, Hesselink MK, Schrauwen P: Re-evaluating lipotoxic triggers in skeletal muscle: Relating intramyocellular lipid metabolism to insulin sensitivity. Prog Lipid Res 2012;51:36-49.

$>19$ Harasim E, Stepek T, Konstantynowicz-Nowicka K, Baranowski M, Gorski J, Chabowski A: Myocardial lipid profiling during time course of high fat diet and its relationship to the expression of fatty acid transporters. Cell Physiol Biochem 2015;37:1147-1158.

20 Lee S, Boesch C, Kuk JL, Arslanian S: Effects of an overnight intravenous lipid infusion on intramyocellular lipid content and insulin sensitivity in african-american versus caucasian adolescents. Metabolism 2013;62:417-423.

-21 van Loon LJ, Goodpaster BH: Increased intramuscular lipid storage in the insulin-resistant and endurancetrained state. Pflugers Arch 2006;451:606-616.

22 Fayyaz S, Japtok L, Kleuser B: Divergent role of sphingosine 1-phosphate on insulin resistance. Cell Physiol Biochem 2014;34:134-147.

23 Miklosz A, Lukaszuk B, Baranowski M, Gorski J, Chabowski A: Effects of inhibition of serine palmitoyltransferase (spt) and sphingosine kinase 1 (sphk1) on palmitate induced insulin resistance in 16 myotubes. PLoS One 2013;8:e85547.

24 Itani SI, Ruderman NB, Schmieder F, Boden G: Lipid-induced insulin resistance in human muscle is associated with changes in diacylglycerol, protein kinase c, and ikappab-alpha. Diabetes 2002;51:20052011.

25 Turner N, Cooney GJ, Kraegen EW, Bruce CR: Fatty acid metabolism, energy expenditure and insulin resistance in muscle. J Endocrinol 2014;220:T61-79.

-26 Kurek K, Miklosz A, Lukaszuk B, Chabowski A, Gorski J, Zendzian-Piotrowska M: Inhibition of ceramide de novo synthesis ameliorates diet induced skeletal muscles insulin resistance. J Diabetes Res 2015;2015:154762.

-27 Selathurai A, Kowalski GM, Burch ML, Sepulveda P, Risis S, Lee-Young RS, Lamon S, Meikle PJ, Genders AJ, McGee SL, Watt MJ, Russell AP, Frank M, Jackowski S, Febbraio MA, Bruce CR: The cdp-ethanolamine pathway regulates skeletal muscle diacylglycerol content and mitochondrial biogenesis without altering insulin sensitivity. Cell Metab 2015;21:718-730.

28 Chabowski A, Zendzian-Piotrowska M, Nawrocki A, Gorski J: Not only accumulation, but also saturation status of intramuscular lipids is significantly affected by ppargamma activation. Acta Physiol (Oxf) 2012;205:145-158.

29 Lukaszuk B, Miklosz A, Chabowski A, Gorski J: Modest decrease in pgc1alpha results in tag accumulation but not in insulin resistance in 16 myotubes. Cell Physiol Biochem 2015;35:1609-1622.

-30 Lee YS, Li P, Huh JY, Hwang IJ, Lu M, Kim JI, Ham M, Talukdar S, Chen A, Lu WJ, Bandyopadhyay GK, Schwendener R, Olefsky J, Kim JB: Inflammation is necessary for long-term but not short-term high-fat diet-induced insulin resistance. Diabetes 2011;60:2474-2483.

-31 Correia JC, Ferreira DM, Ruas JL: Intercellular: Local and systemic actions of skeletal muscle pgc-1s. Trends Endocrinol Metab 2015;26:305-314.

-32 Smyth S, Heron A: Diabetes and obesity: The twin epidemics. Nat Med 2006;12:75-80.

-33 Oberkofler H, Linnemayr V, Weitgasser R, Klein K, Xie M, Iglseder B, Krempler F, Paulweber B, Patsch W: Complex haplotypes of the pgc-1alpha gene are associated with carbohydrate metabolism and type 2 diabetes. Diabetes 2004;53:1385-1393.

34 Hara K, Tobe K, Okada T, Kadowaki H, Akanuma Y, Ito C, Kimura S, Kadowaki T: A genetic variation in the pgc-1 gene could confer insulin resistance and susceptibility to type ii diabetes. Diabetologia 2002;45:740743.

-35 Mootha VK, Lindgren CM, Eriksson KF, Subramanian A, Sihag S, Lehar J, Puigserver P, Carlsson E, Ridderstrale M, Laurila E, Houstis N, Daly MJ, Patterson N, Mesirov JP, Golub TR, Tamayo P, Spiegelman B, Lander ES, Hirschhorn JN, Altshuler D, Groop LC: Pgc-1alpha-responsive genes involved in oxidative phosphorylation are coordinately downregulated in human diabetes. Nat Genet 2003;34:267-273.

-36 Patti ME, Butte AJ, Crunkhorn S, Cusi K, Berria R, Kashyap S, Miyazaki Y, Kohane I, Costello M, Saccone R, Landaker EJ, Goldfine AB, Mun E, DeFronzo R, Finlayson J, Kahn CR, Mandarino LJ: Coordinated reduction of genes of oxidative metabolism in humans with insulin resistance and diabetes: Potential role of pgc1 and nrf1. Proc Natl Acad Sci USA 2003;100:8466-8471. 


\section{Cellular Physiology Cell Physiol Biochem 2015;37:2288-2296 \begin{tabular}{ll|l|l} 
DOI: 10.1159/000438584 & $\begin{array}{l}\text { O 2015 The Author(s). Published by S. Karger AG, Basel } \\
\text { www.karger.com/cpb }\end{array}$ \\
and Biochemistry Published online: December 02, 201 &
\end{tabular}}

Łukaszuk et al.: PGC-1 $\alpha$ and Muscular Insulin Resistance

-37 Naples SP, Borengasser SJ, Rector RS, Uptergrove GM, Morris EM, Mikus CR, Koch LG, Britton SL, Ibdah JA, Thyfault JP: Skeletal muscle mitochondrial and metabolic responses to a high-fat diet in female rats bred for high and low aerobic capacity. Appl Physiol Nutr Metab 2010;35:151-162.

38 Lin J, Wu PH, Tarr PT, Lindenberg KS, St-Pierre J, Zhang CY, Mootha VK, Jager S, Vianna CR, Reznick RM, Cui L, Manieri M, Donovan MX, Wu Z, Cooper MP, Fan MC, Rohas LM, Zavacki AM, Cinti S, Shulman GI, Lowell BB, Krainc D, Spiegelman BM: Defects in adaptive energy metabolism with cns-linked hyperactivity in pgc1alpha null mice. Cell 2004;119:121-135.

-39 Summermatter S, Baum O, Santos G, Hoppeler H, Handschin C: Peroxisome proliferator-activated receptor \{gamma\} coactivator 1 alpha\} (pgc-1 \{alpha\}) promotes skeletal muscle lipid refueling in vivo by activating de novo lipogenesis and the pentose phosphate pathway. J Biol Chem 2010;285:32793-32800.

$>40$ Choi CS, Befroy DE, Codella R, Kim S, Reznick RM, Hwang YJ, Liu ZX, Lee HY, Distefano A, Samuel VT, Zhang D, Cline GW, Handschin C, Lin J, Petersen KF, Spiegelman BM, Shulman GI: Paradoxical effects of increased expression of pgc-1alpha on muscle mitochondrial function and insulin-stimulated muscle glucose metabolism. Proc Natl Acad Sci USA 2008;105:19926-19931.

41 Calvo JA, Daniels TG, Wang X, Paul A, Lin J, Spiegelman BM, Stevenson SC, Rangwala SM: Muscle-specific expression of ppargamma coactivator-1alpha improves exercise performance and increases peak oxygen uptake. J Appl Physiol (1985) 2008;104:1304-1312.

42 Espinoza DO, Boros LG, Crunkhorn S, Gami H, Patti ME: Dual modulation of both lipid oxidation and synthesis by peroxisome proliferator-activated receptor-gamma coactivator-1alpha and -1beta in cultured myotubes. FASEB J 2010;24:1003-1014.

43 Hoeks J, Arany Z, Phielix E, Moonen-Kornips E, Hesselink MK, Schrauwen P: Enhanced lipid-but not carbohydrate-supported mitochondrial respiration in skeletal muscle of pgc-1alpha overexpressing mice. J Cell Physiol 2012;227:1026-1033.

-44 Kiens B: Skeletal muscle lipid metabolism in exercise and insulin resistance. Physiol Rev 2006;86:205-243. Altshuler B: Modeling of dose-response relationships. Environ Health Perspect 1981;42:23-27.

-46 Vandenberg LN, Colborn T, Hayes TB, Heindel JJ, Jacobs DR, Jr., Lee DH, Shioda T, Soto AM, vom Saal FS, Welshons WV, Zoeller RT, Myers JP: Hormones and endocrine-disrupting chemicals: Low-dose effects and nonmonotonic dose responses. Endocr Rev 2012;33:378-455.

47 Los M, Maddika S, Erb B, Schulze-Osthoff K: Switching akt: From survival signaling to deadly response. Bioessays 2009;31:492-495.

48 Benton CR, Wright DC, Bonen A: Pgc-1alpha-mediated regulation of gene expression and metabolism: Implications for nutrition and exercise prescriptions. Appl Physiol Nutr Metab 2008;33:843-862.

49 Irrcher I, Adhihetty PJ, Sheehan T, Joseph AM, Hood DA: Ppargamma coactivator-1alpha expression during thyroid hormone- and contractile activity-induced mitochondrial adaptations. Am J Physiol Cell Physiol 2003;284:C1669-1677.

50 Lai L, Leone TC, Zechner C, Schaeffer PJ, Kelly SM, Flanagan DP, Medeiros DM, Kovacs A, Kelly DP: Transcriptional coactivators pgc-1alpha and pgc-lbeta control overlapping programs required for perinatal maturation of the heart. Genes Dev 2008;22:1948-1961.

-51 Puigserver P, Wu Z, Park CW, Graves R, Wright M, Spiegelman BM: A cold-inducible coactivator of nuclear receptors linked to adaptive thermogenesis. Cell 1998;92:829-839.

52 Chan MC, Arany Z: The many roles of pgc-1alpha in muscle--recent developments. Metabolism 2014;63:441-451. 